\title{
Histop Athological Comparision of Mast Cell Density in Various Grades of Mucoepidermoid Carcinoma
}

\author{
Farzad Yazdani ${ }^{1}$, Gita Rezvani ${ }^{2}$, Sajad Safari ${ }^{2}$, Maryam Jaberi ${ }^{3}$ \\ ${ }^{1}$ Amir Alam Hospital Tehtran University of Medical Sciences, Tehran, Iran \\ ${ }^{2}$ Shahed University, Dentistry School, Tehran, Iran \\ ${ }^{3}$ Tehran University of Medical School, Tehran, Iran \\ Email address: \\ farzadyazdani2000@yahoo.com (F. Yazdani),gitarez@yahoo.com (G. Rezvani), Dr.SajadSafari@gmail.com (S. Safari), \\ mj_18141@yahoo.com (M. Jaberi)
}

\section{To cite this article:}

Farzad Yazdani, Gita Rezvani, Sajad Safari, Maryam Jaberi. Histop Athological Comparision of Mast Cell Density in Various Grades of Mucoepidermoid Carcinoma. Cancer Research Journal. Vol. 3, No. 5, 2015, pp. 100-103. doi: 10.11648/j.crj.20150305.12

\begin{abstract}
Mucoepidermoid carcinoma (MEC) is one of most prevalent carcinomas of salivary glands in which the histoathological grading is very important in treatment and prognosis. In this study we are going to compare mast cell density in different kinds of mucoepidermoid grading by Toluidine blue staining. Materials and Methods. Paraffin blocks of 19 cases of low grade and 21 cases of high grade mucoepidermoid carcinoma were selected and stained by toluidine blue.The number of mast cells were observed in two manners(absolute and ordinal).T student was used for absolute counting and Mann Whitney for ordinal counting. in absolute counting,we defined a number for counting, for ordinal counting, we defined an interval range for mast cell numbers. Results. In absolute Counting,the mean of mast cell density in low grade cases was $19.7+/-15.7$ and in high grade cases was $20.3+/-21.07$ and there was no significant difference between two groups( $\mathrm{p}=0.920)$. In ordinal counting, there was no significant difference between two groups in mast cell density $(p=0.729)$. Conclusion. According to this study, the mast cell counting can not be used for histopathological grading of MEC.
\end{abstract}

Keywords: Mast Cell, Histopathological Grading, Mucoepidermoid Carcinoma

\section{Introduction}

Mucoepidermoid carcinoma is one of most prevalent salivary gland tumors with variable Biological behavior which can behave indolent to very aggressive(1). Histopathological grading of this tumor has a great role in treatment and prognosis, so must be determined definitely(2).Multiple grading systems have been defined for this tumor by now, like: AFIP,Brand wein,Modified healy. Modified healy is the most prevalent, in this system, histological grade is assumed by proportion of epithelial cells to mucinous cells and the degree of cyst formation(3)

Multiple diagnostic techniques have been detected for determining mucoepidermoid carcinoma prognosis which they need too money and time, and some of them special conditions, so findig a technique which can detect tumor grade in fixed paraffin blocks in a short period of time has a significant role in tumor progression and metastasis and can help to determine mucoepidermoid carcinoma grading.

Mast cell is one of inflammatory cells with multiple biological activities like wound repair, tissue removal, cell proliferation and some antigen reactions, most of the mast cell activity is done by inflammatory mediators like histamine, proteoglycan, protease, leukoterines and prostaglandins which most of them have role in angiogenesis, extracellular matrix destruction, mitogenesis and immunosuppression which promote tumorgenesis in some malignancies with these mechanisms(4)

In this study, we are going to compare mast cell density in various grades of mucoepidermid carcino, a by Toluidine blue staining

\section{Materials and Methods}

We selected 40 paraffin blocks of patients with mucoepidermoid carcinoma which had good quality and enough tissue from Emam Khomeini and Amir Alam hospitals archives and then cut with microtome apparatus 3 to 4 micrometer from each paraffin blocks and laid on slides and heat them in autoclave with 60 degree centigrade and deparaffinized with xylol and ultimately watered with 
different alchohol dilutions(up to $70 \%$ ) and stained with $\mathrm{H} \& \mathrm{E}$ and Toluidine blue, each for ten minutes, after washing and drying the slides, they were mounted.

Mast cells were counted in each surface area by optical microscope Olympus with 400 magnification in stroma of the tumor, preferably out of inflamed areas and in tumor periphery, in two manners: absolute and ordinal.

Histopathological grading of mucoepidermoid carcinoma in specimens were separately determined by two pathologists with Modified healy system.

For absolute counting T-student test and for ordinal counting Mann Whitney test were used.

\section{Results}

Specimens were 40, including 19 cases of low grade and 21 cases of high grade mucoepidermoid carcinoma.
Table number 1 shows absolute mast cell count in two groups of low grade and high grade mucoepidermoid carcinoma, in 19 low grade cases, minimum mast cell in surface area unit was 3 and maximum was 65 and mean of mast cells was $19.7+-15.7$.In 21 high grade cases, minimum of mast cells was 3 and maximum was 86 and mean of mast cells was $20.3+-21.7$, with $\mathrm{T}$ student test there was no significant differences between two groups of mucoepidermoid carcinoma $(p=.0920)$

Bar chart number one shows mast cells in surface area unit with confidence interval of $95 \%$ in two grades of mucoepidermoid carcinoma.

Results of ordinal counting is in table number 2 which with Mann Whitney there was no significant difference in mast cell density in two groups $(\mathrm{p}==.0729)$

We must mention that $92.5 \%$ agreement was seen between two observers.

Table 1. Mast cell density in two grades of mucoepidermoid cardinoma(absolute counting).

\begin{tabular}{lllllll}
\hline grade & & N & Minimum & Maximum & Mean & Std. Deviation \\
\hline \multirow{2}{*}{ low } & mast.cell & 19 & 3.00 & 65.00 & 19.7368 & 15.75804 \\
& Valid N (listwise) & 19 & & & & \\
& mast.cell & 21 & 3.00 & 86.00 & 20.3333 & 21.07922 \\
& Valid N (listwise) & 21 & & & & \\
\hline
\end{tabular}

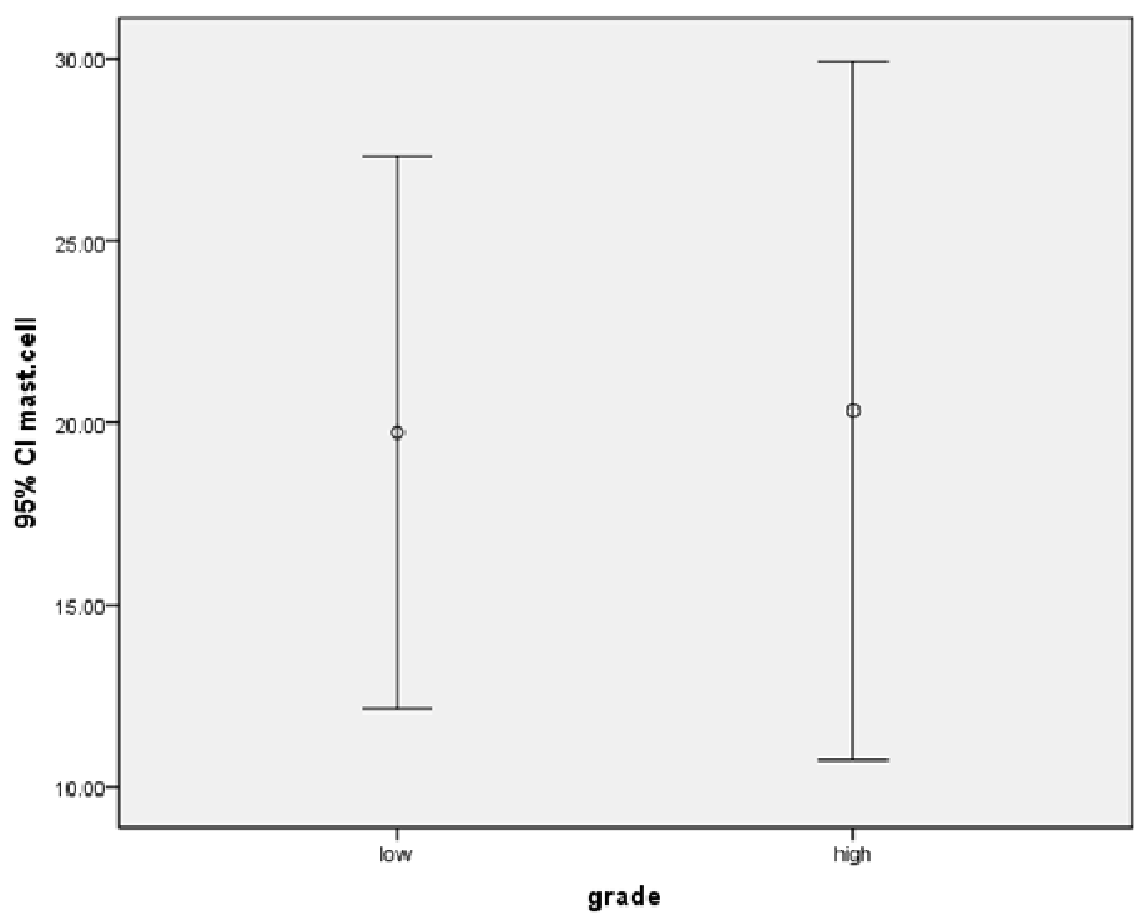

Bar Chart 1. Mast cell density in surface area unit in two grades of mucoepidermoid carcinoma.

Table 2. Mast cell density in two grades of mucoepidermoid carcinoma(ordinal counting).

\begin{tabular}{|c|c|c|c|c|c|c|c|c|}
\hline & & & mast.ce & & & & & \\
\hline \multirow{5}{*}{ grade } & .00 & 1.00 & 2.00 & 3.00 & 4.00 & 5.00 & & \\
\hline & low & Count & 4 & 5 & 4 & 3 & 0 & 2 \\
\hline & & $\%$ within grade & $21.1 \%$ & $26.3 \%$ & $21.1 \%$ & $15.8 \%$ & $.0 \%$ & $10.5 \%$ \\
\hline & high & Count & 5 & 6 & 5 & 2 & 1 & 0 \\
\hline & & $\%$ within grade & $23.8 \%$ & $28.6 \%$ & $23.8 \%$ & $9.5 \%$ & $4.8 \%$ & $.0 \%$ \\
\hline Total & & Count & 9 & 11 & 9 & 5 & 1 & 2 \\
\hline
\end{tabular}


Table 2. (continue).

\begin{tabular}{|c|c|c|c|c|c|c|}
\hline & & & \multicolumn{3}{|c|}{ mast.cell.grade } & \multirow{2}{*}{ Total } \\
\hline & & & 6.00 & 7.00 & 10.00 & \\
\hline \multirow{4}{*}{ grade } & \multirow{2}{*}{ low } & Count & 1 & 0 & 0 & 19 \\
\hline & & $\%$ within grade & $5.3 \%$ & $.0 \%$ & $.0 \%$ & $100.0 \%$ \\
\hline & \multirow{4}{*}{ high } & Count & 0 & 1 & 1 & 21 \\
\hline & & $\%$ within grade & $.0 \%$ & $4.8 \%$ & $4.8 \%$ & $100.0 \%$ \\
\hline \multirow{2}{*}{ Total } & & Count & 1 & 1 & 1 & 40 \\
\hline & & $\%$ within grade & $2.5 \%$ & $2.5 \%$ & $2.5 \%$ & $100.0 \%$ \\
\hline
\end{tabular}

\section{Discussion and Conclusion}

Histopathological grading of mucoepidermoid carcinoma is too important in treatment and prognosis so it is really important to determine histological grading.(2)By now, many studies have been done to determine histpathological grading of salivary gland tumors(5), in this study, due to role of mast cells in determining benign from malignant, mast cells with staining with Toluidine blue was used to determine histological grading and showed that mast cell density was more in high grade tumors than low grade ones although, this difference was not statistically important.

Tumor histopathology grade shows degree of differentiation, when tumor is more differentiated, it is more similar to native cells either in morphology or in function and velocity of growth of the tumor is contrary to its differentiation.(6)

Mast cells induce production of TNF,TGF,... which have roles in tumor differentiation and growth so more density mast cells lead to more poorly differentiated tumors(6)so indirectly can influence tumor histological grade.

Since, grading of mucoepidermoid carcinoma is very important in treatment and overall survival of patients, we tried to show if mast cell numbers can be used in grading system and in tumor biological behavior and metastasis, this was the most important aim of the study.

This matter was the base of this study and we showed that mast cell density was more in high grade MEC than low grade ones which this difference was not statistically remarkable.

Some reasons for this results can be low amount of mediators secreted, low volume of the sample or inpropper target cell(MEC cells),it is important to emphasize that mast sell role is more important in angiogenesis than cell proliferation so it may have greater role in stage of tumor than the grade.

In recent study ba Dr Etemadi and colleagues in SCC of oral cavity, they showed mast cells have role in primary stages of tumor and after invasion may be mast cells does not have role because they also did not find any relation between tumor grade and mast cell density(7).

Some studies have shown more mast cells in higher grade of malignancies like SCC,BCC(8)but in our study and Etemadi Moghadam study this matter was disapproved.

In 2010, Parizi and colleagues showed no significant difference in mast cell density in various grades in $30 \mathrm{SCC}$ of skin and 34 SCC of oral cavity(9)

In 2010,Mohtasham and colleagues showed more mast cell density with more angiogenesis in high grade oral cavity $\mathrm{SCC}$ and said may be mast cell can induce angiogenesis by mast cell triptase (10)

In 2013, widal and colleagues show ed the most mast cell density in MEC and the least in pleomorphic adenoma,but they not studied in various grade of MEC(11)

Some limitations in this study are low sample volume, not specific tumor site, non sensitive staining method and grading system so we suggest studies with larger sample volume, tumor with more specific site, more precise staining method and tumor grading system

\section{Conclusion}

Mast cell density was the same in high and low grade MEC in this study

\section{References}

[1] Neville BW, Damm DD, Allen CM, Bouquot JE. Oral and maxillofacial pathology. 3rd ed., Missouri: Saunders Elsevier; 2009 p.

[2] Regezi JA, Scuibba JJ, Jordan RCK. Oral Pathology: clinical Pathology correlation. 5th ed., Missouri: Sunders Elsevier; 2008. P.203-207

[3] Seethala RR. An Update on Grading of salivary Gland Carcinomas. Head Neck Pathol. 2009;3(1): 69-77.

[4] Majidi A. Evaluation of mast cell density in differential diagnosis of Enchondroma and high grade chondrosarcoma. [Doctorate Thesis]. Iran. Dental school of Shahed University; 2009. (Persian)

[5] Seethala RR. Histologic Grading and Prognostic Biomarkers in Salivary Gland Carcinomas. Adv Anat Pathol. 2011;18(1):29-45

[6] Kumar V, Abul Abbas K, Fausto N, Mithhell R. Robbins Basic Pathology. 8th Ed, Kenedy: Saunders Elsevier; 2007p.

[7] Etemad-Moghadam Sh, Gholamhosseini A, Khorshidian A, Alaeddini M. Compasison of mast cell density in hitologic differentiation of oral squamous cell carcinoma based on three different valid grading systems $j$ Isfahan Dent Sch 2014;9(6):509-17

[8] Aolci M, Pawanckar R, Niimi Y: Masst cell in basal cell carcinoma express VEGF, IL-8 and RANTES. Int Arch Allergy Immunol 2003; 130: 216-223

[9] Parizi AC, Barbosa RL, Parizi JL, Nai GA. A comparison between the concentration of mast cell in scc of the skin and oral catity. An Bras Dematol 2010 Nov-Dec; 85(6):811-8. 
[10] Mohtasham N, Babakoohi S, Salehinejad J, MontaserKouhsariL, Shakeri MT, Shojaee S et al. Mast cell density and angiogenesis in oral dysplastic epithelium and low and high grade oral squamous cell carcinoma. Acta Odontol Scand 2010;68:300-304
[11] Vidal MI, de Oliveria Araujo IB, Gurgel CA, Pereira Fde A, vilas-Boas Ds, Ramos EA, et al. tumor Biol. 2013;34(1):30916.Density of mast cells and microvessels in minor salivary gland tumors. 